\title{
Birth trauma to muscles in babies born by breech delivery and its possible fatal consequences
}

\author{
Z. A. RÁLIŚ \\ From Cardiff Royal Infirmary
}

\begin{abstract}
Ráliš, Z. A. (1975). Archives of Disease in Childhood, 50, 4. Birth trauma to muscles in babies born by breech delivery and its possible fatal consequences. Dissection and histological examination was made of the muscles of 86 babies who died after breech delivery, and of 38 babies who died after vertex presentation. A control group of 50 surviving breech-delivered babies was examined clinically and the results compared. It was concluded that the most common type of birth trauma to a baby born by breech delivery is injury to muscles and soft tissues of the back and lower extremities, which is often extensive. In some severely injured babies histological examination of organs reveals signs of crush syndrome and disseminated intravascular coagulation. It is suggested that the extensive muscle trauma forms the background of these fatal conditions.
\end{abstract}

The mortality of babies born by breech presentation exceeds the average neonatal mortality rate by 15 to 20 times, reaching 5 to $15 \%$ (Kauffler, 1941; Elefant 1957; Burger, Milfort, and Denef, 1962). Birth trauma is supposed to be the main factor responsible. Despite attempts to reduce the high mortality rate, the figures are still alarming and the problem is far from being solved.

Birth injuries in breech delivery do not involve only the CNS; a recent survey based on published reports during the last 45 years has shown that breech delivery, especially when assisted, is the main cause of birth injuries to the liver, anus, genitalia, spine, spinal cord, all long bones, hip joint, and sciatic nerve (Ráliš 1968a). Trauma to muscles, however, though the most frequent and typical consequence of breech delivery, is less well recognized, and it is only trauma of the sternomastoid muscle that is mentioned, because of the evident relation between breech delivery and torticollis or clinically evident sternomastoid 'tumour'. Trauma to and haemorrhage into the muscles of the lower back and lower extremities, though often deep and extensive, is usually considered to be superficial subcutaneous bruising similar to caput succedaneum (Fig. 1).

This study is mainly concerned with injuries to the muscles in breech born babies.

Received 11 June 1974.

\section{Material and methods}

During the past 10 years necropsy dissections of the muscles of 86 babies born by breech presentation and of 38 babies born by vertex presentation were carried out. In addition, 50 living term babies born by breech delivery were clinically examined during the first week after birth (Table I). The series of dissections was started in the Department of Traumatic and Orthopaedic Surgery and the Department of Pathology, Faculty of Paediatrics, Charles University, Prague, and completed in the Department of Pathology, Sheffield Children's Hospital and Congenital Anomalies Research Unit, Department of Child Health, University of Sheffield. 77 of the 86 breech-born babies dissected were selected at random from the pathological department which necropsied all fetuses and babies who died in the maternity hospitals during or immediately after birth, as well as those babies who died later in the Children's Hospital. The remaining 9 babies dissected were randomly selected from those who survived breech delivery and died in the Children's Hospital. The living babies were examined in the Maternity Hospital, Faculty of Pacdiatrics, Prague, and the Children's Hospital, Sheffield.

Post-mortem dissections. Table I shows the distribution and maturity ratio of the 124 babies dissected; of 86 children born by breech presentation, two-thirds were preterm. Their age and sex are shown in Table II. $46 \%$ of the mothers were primipara and their average age was 25.5 years. $40 \%$ of the babies were born by breech extraction. 


\section{TABLE I}

Total cases seen

\begin{tabular}{c|c|c|c|c|c|}
\hline & \multicolumn{1}{c|}{ Post-mortem dissections } & Clinical examination \\
\cline { 2 - 4 } & $\begin{array}{c}\text { Breech } \\
\text { presentation }\end{array}$ & $\begin{array}{c}\text { Vertex } \\
\text { presentation }\end{array}$ & Breech presentation \\
\hline Term babies & 26 & 18 & 50 \\
\hline Preterm babies & 60 & 20 & -94 \\
\hline Total & 86 & 38 & 50 \\
\hline
\end{tabular}

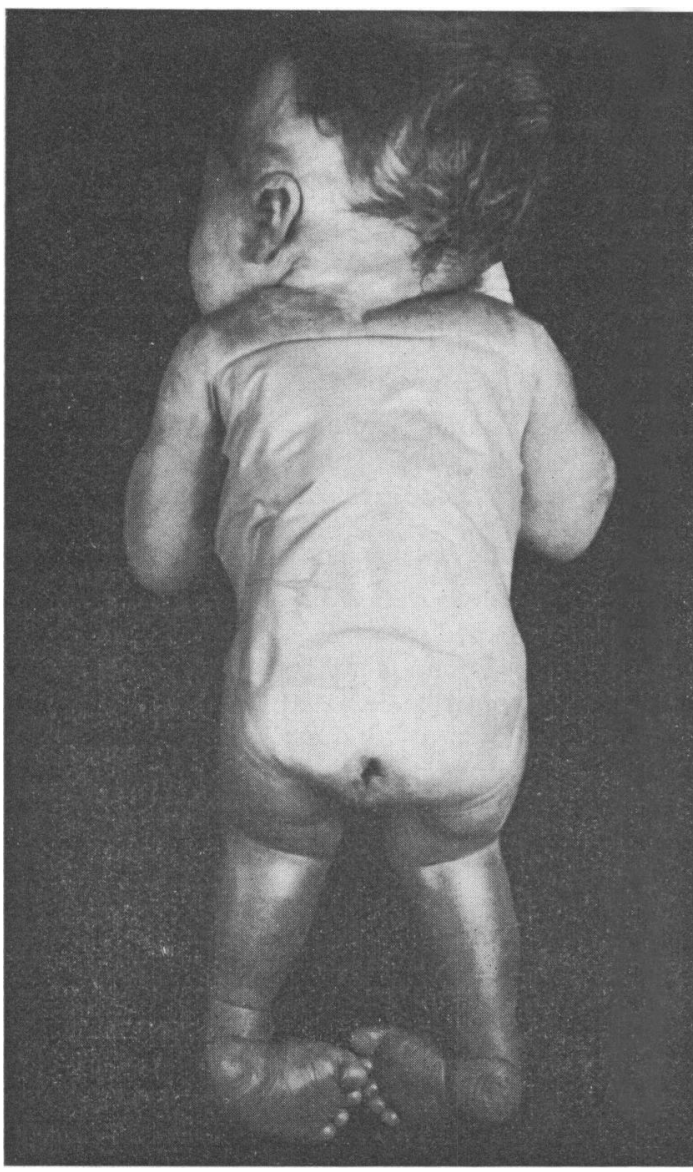

FIG. 1.-The dark discoloration of legs in this premature breech-born baby was clinically described as 'localized cyanosis and asphyxia' and 'possible deep vein thrombosis'. The child survived the assisted breech delivery for 48 hours. Dissection revealed diffuse damage and haemorrhage of second and third degree of most of the muscles and nerves of lower extremities.
TABLE II

Age and sex of 86 babies who died after breech delivery and were dissected

\begin{tabular}{l|l}
\hline Age & \\
Stillborn & $24 \%$ \\
$0-2 \mathrm{~h}$ & $19 \%$ \\
$2-24 \mathrm{~h}$ & $21 \%$ \\
$1-7 \mathrm{~d}$ & $21 \%$ \\
More than 7 d & $15 \%$ \\
Sex & \\
Males & \\
Females & $57 \%$ \\
& $43 \%$ \\
\hline
\end{tabular}

Routine post-mortem examinations were done in all cases and the spinal canal was opened in most of them. All areas of the skin, subcutaneous tissue, muscles, large nerves, and joints where birth trauma was expected were dissected. In addition, the lower extremities were dissected in all babies, whether or not any birth injury was apparent. The topography and extent of haemorrhage in all tissues were recorded. Blocks for microscopical examinations were taken from all specimens and the sections stained by routine histological methods. All data were put on punch cards and results calculated from these.

Living newborn babies. 50 living babies ( 30 boys and 20 girls) were examined during the first week after their breech delivery. They were all term babies; $35 \%$ of them had a birthweight over $3.5 \mathrm{~kg}$. Any injuries of the skin, subcutaneous tissue, and organs found on clinical examination were recorded and these findings were compared with the data obtained from the dissected group.

\section{Results}

\section{Post-mortem dissections-breech delivery ( 86 babies).}

Skin and subcutaneous tissue. Skin damage was the most obvious. The changes ranged from tense, shiny, reddish skin to 'gangrenous' appearance of purple-black epidermis with blisters suggesting a 
severe degree of post-traumatic oedema. The damage was found mainly in the gluteal region and in certain parts of the legs and trunk. Approximately $30 \%$ of skin from all lower limbs dissected was damaged to some extent (Table III).

TABLE III
Skin and muscle damage in 172 babies dying after
breech delivery

\begin{tabular}{l|c|c}
\hline & $\begin{array}{c}\text { Skin damage } \\
(\% \text { cases })\end{array}$ & $\begin{array}{c}\text { Muscle damage } \\
(\% \text { cases })\end{array}$ \\
\hline Gluteal region & 36 & 76 \\
Thigh & 27 & 46 \\
Lower leg & 33 & 30 \\
Foot & 30 & 25 \\
\hline
\end{tabular}

Haemorrhage into the subcutaneous tissue occurred mainly in preterm babies and followed the pattern of the skin damage. In term babies there was often a startling difference between the intact skin and subcutaneous tissue present and the black mass of severely damaged muscles underneath. This fact could be clinically very important: in nearly half of the cases dissected there was no skin damage apparent over the injured gluteal or thigh muscles. Subcutaneous necrosis of the skin was not found, but sclerema of the lateral side of the thighs was seen twice and thrombosis of the long saphenous vein was found in one case.

Muscles of the lower extremities. Table IV shows the frequency and amount of muscle damage and haemorrhage in dissected individual muscles from lower extremities. It is seen, for example, that $70 \%$ of all gluteus maximus muscles dissected were damaged to some extent, and that the average volume of the muscle mass found to be damaged was $50 \%$. The localization of the damage in individual muscles and the topographical distribution often followed a typical pattern.

Histologically, various degrees of haemorrhage, damage to muscle fibres, vascular damage and thrombosis, reparative changes and healing by fibrosis were seen. According to the intensity of haemorrhage, a scale of three degrees was used: the first degree showed oedema with extreme passive hyperaemia, small perivascular haemorrhages, and slight bleeding into the perimysial connective tissue. In the second degree, haemorrhage in the perimysium was diffusely spread and there was some bleeding in the endomysium. In the most severe trauma -in which the injured muscles appeared as a black tar-like mass (third degree) all connective
TABLE IV

Incidence and amount of muscle damage in dissected lower extremities of babies dying after breech delivery

\begin{tabular}{l|c|c}
\hline \multicolumn{1}{c|}{ Muscle } & $\begin{array}{c}\text { Frequency of } \\
\text { muscles involved } \\
\text { (\% of all muscles } \\
\text { dissected) }\end{array}$ & $\begin{array}{c}\text { Average size of } \\
\text { damaged area } \% \\
\text { of total mass of } \\
\text { dissected muscle) }\end{array}$ \\
\hline Gluteus maximus & 70 & 50 \\
Gluteus medius & 60 & 48 \\
Gluteus minimus & 45 & 48 \\
Piriformis & 31 & 48 \\
Obturator internus & 31 & 70 \\
Gemelli & 17 & 46 \\
Obturator externus & 17 & 82 \\
Quadratus femoris & 35 & 38 \\
Sartorius & 30 & 35 \\
Rectus femoris & 50 & 38 \\
Vastus lateralis & 24 & 36 \\
Vastus intermedius & 26 & 45 \\
Vastus medialis & 24 & 43 \\
Adductor muscles & 10 & 39 \\
Iliopsoas (extrapelvic) & 22 & 49 \\
Biceps femoris & 16 & 49 \\
Semitendinosus & 18 & 40 \\
Semimembranosus & 41 & \\
Foreleg muscles & & \\
\hline
\end{tabular}

tissue spaces in the muscle were filled with blood and individual muscle fibres were separated by crowded red blood cells (Fig. 2).

Muscle fibres in the areas of haemorrhage and also around them showed a considerable amount of damage. The changes depended on the intensity of haemorrhage, the duration of labour and the length of survival. All degrees of muscle fibre damage were present, ranging from cloudy swelling and loss of cross striation, through partial degeneration and fragmentation, up to total necrosis of fibres with extensive macrophagic reaction and phagocytosis of their remains (Figs. 2 and 3). Apart from destructive changes, the regeneration of muscle fibres and proliferation of young connective tissue could be seen in some areas 36 to $\mathbf{4 8}$ hours after birth.

In some muscles of those infants who survived 4 to 6 weeks after breech delivery the necrotic zone was replaced by dense fibrotic tissue; some of its elements gave a positive haemosiderin reaction. As this late scarring and permanent structure damage to injured muscles and nerves may be responsible for a 'congenital' orthopaedic deformity of the growing limb, its detailed anatomy, topographical distribution, and orthopaedic aspects are discussed in a separate report.

In the present study the general and possibly fatal aspects of the injuries are discussed. For this purpose an attempt has been made to assess the quantitative factors of the damage, i.e. the total 


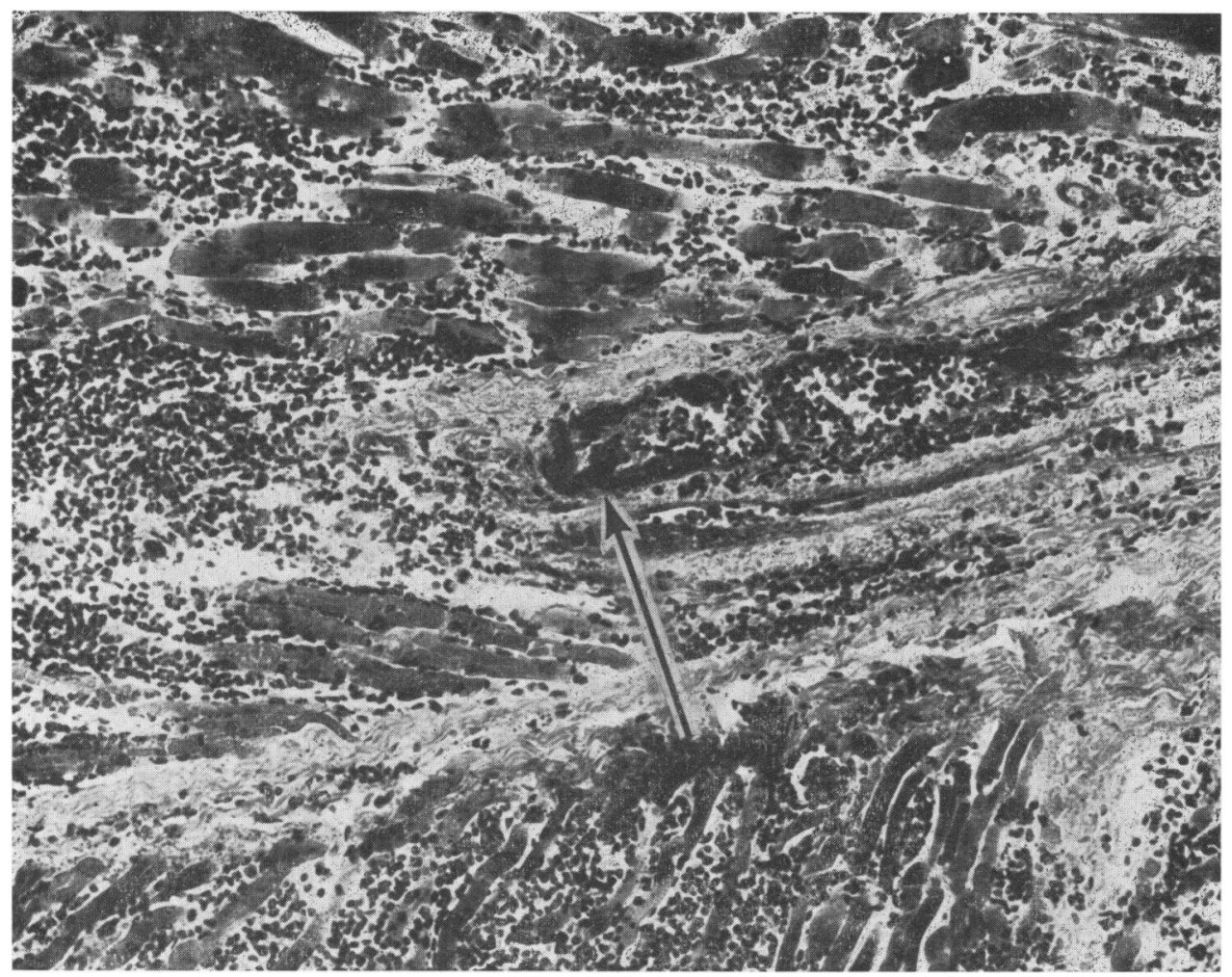

Fig. 2.-Microscopical appearance of the damaged gracilis muscle in a premature baby who died 5 days after breech delivery. Damage to muscle fibres and haemorrhage of third degree. The vessel in the centre of the figure (arrow) contains an adherent fibrin-positive thrombus. (Goldner's Trichrome. $\times 85$.)

volume of muscle mass damaged and the amount of blood that escaped from circulation and was arrested in it.

The final figures obtained from detailed calculations indicate that the total amount of damaged muscles in these neonates represents on average $38 \%$ of total muscle mass of their lower extremities. The author has recently weighed all the individual muscles from lower extremities in more than 30 newborn babies of various ages and maturity who have died from causes unrelated to any damage of the locomotor system. These measurements when correlated with body weight showed that the total muscle mass of lower extremities in the newborn is on average $6.6 \%$ of its body weight. Provided that on average $38 \%$ of their leg muscle mass was damaged, as was the case in the breech-born babies dissected, this represents a muscle mass equivalent to $2.5 \%$ of the child's body weight. In a preterm baby (about $1500 \mathrm{~g}$ ) this would be $37.5 \mathrm{~g}$ and in a term baby (about $3 \cdot 500 \mathrm{~g}$ ) it would be $87 \cdot 5 \mathrm{~g}$. Only the damaged muscles of the lower extremity were involved in this calculation; as there was also frequent damage of muscles of the neck and lower back, this average figure would have been higher if all the damaged muscles had been considered.

The blood volume is $108 \mathrm{ml} / \mathrm{kg}$ body weight in preterm babies and $85 \mathrm{ml} / \mathrm{kg}$ in term babies (Smith, 1966). Another figure quoted is $12 \%$ of the body weight. Thus, a preterm baby has about $150-200$ $\mathrm{ml}$ and a term baby about $300-400 \mathrm{ml}$ of circulating blood. In the present series the amount of damaged muscle mass with haemorrhage is the weight equivalent of $1 / 5-1 / 4$ of the total circulating blood. It is, of course, practically impossible to estimate quantitatively the exact volume of arrested blood per volume unit of the damaged muscle, and our figures, therefore, can only be approximate. On the other hand, however, the quoted figures are taken on average for all the cases dissected. In some individual cases they would be 2 to 3 times higher. 




FIG. 3.-Gracilis muscle of a premature baby who died 4 days after breech delivery. This area of extensive muscle necrosis does not lie in the zone directly involved in haemorrhage. Mechanical trauma and ischaemia are the likely causes of this damage to contractile muscle elements. (Haematoxylin and eosin. $\quad \times 85$.

Other muscles. Trauma to muscles in other parts of the body was more frequent than expected. Its topographical distribution depended on the type of breech delivery. Maximum damage was found in whichever part of the body was either leading, obstructed, or held back during delivery. The muscles most frequently damaged were those of the lower back, spinal and paravertebral muscles, scapular muscles, suboccipital muscles, sternomastoid, temporal, and facial muscles, trapezius, latissimus dorsi, and muscles of the pelvic floor. Occasionally extensive damage to the muscles of the arm was found in cases of delivery with an extended upper extremity. This haemorrhage was usually associated with bleeding into hemithorax and parietal pleura on the same side.

Trauma found on routine post-mortem examination. Damage to the brain was recorded in $48 \%$ of breech-delivered babies. These figures include both damage due to asphyxia and to mechanical trauma. Fracture of the skull was found twice and cephalhaematoma three times, always in the occipital region.

Liver subcapsular haemorrhage was recorded in 6 cases and haemorrhage into adrenals in one.

The anus and genitalia were frequently damaged; this was sometimes the only damage visible on the child. Haemorrhage into the anus was always accompanied with severe bleeding into muscles of the pelvic floor; it was found in one-third of cases. The external genitalia were damaged in about two-thirds of cases. The changes varied in intensity from the haemorrhagic oedema of scrotum and vulva to massive haemorrhagic infarction of all tissues.

Trauma to the testicles was frequent and was obviously of mechanical origin since its prevalence after breech delivery was highly significant when compared with vertex delivery. A severely damaged testicle was found within the inguinal canal in 2 cases. 
Histological changes suggesting the presence of crush syndrome and/or disseminated intravascular coagulation. The author did not have the opportunity to examine histologically every organ in all babies dissected and studied for this report. However, the crush syndrome character of the trauma and the possibility of diagnosing disseminated intravascular coagulation (DIC) by microscopy led to the decision to screen histologically all organs in a selected group of breech-born babies who died with extensive muscle damage. The purpose was to find any positive pathological signs of crush syndrome, shock, or DIC.

From 10 babies completely screened, 6 had survived breech delivery for a period long enough to develop these conditions. They died between 9 hours and 9 days after birth. In 3 of them the following features were found. (1) Moderate to massive obstruction of the distal renal tubules by haemoglobin and pigmented casts. These were sometimes formed by masses of compressed red blood cells or their fragments, or by lumps and clots of fibrin-positive material (Fig. 4). In some areas such casts could be seen in practically all tubules. Many tubules were grossly distended and showed extensive pressure changes and degeneration of their epithelium. These changes do not differ from those seen in the lower nephron in cases of crush syndrome. (2) The presence of scattered microthrombi and deposits of fibrin in capillaries or blood sinuses of organs not directly involved in birth trauma (Fig. 5), together with occasional focal tissue necrosis. Microthrombi were found in sections from lungs, liver, kidneys, and also from badly traumatized muscles. These features represent an episode of DIC, well recognized in connexion with severe stress syndromes, including traumatic and haemorrhagic shock (Hardaway, 1966).

Severity of muscle injury. In order to find support for the hypothesis that in the most severe cases muscle trauma was indeed the main factor responsible for the death of the child, the babies were divided into two groups showing slight or no injury, and severe injury. Trauma with haemorrhage of second and third degree, involving at least one big muscle or several small muscles, was classified as severe trauma. The results showed that there was a significant difference between these two groups in the length of survival, since this was only 2.4 days in the group of severely traumatized babies as compared with 12.2 days in the other group. Thus, the babies with slight or no muscle injury lived five times longer than the severely traumatized babies. The mechanism responsible for severe muscle trauma might of course also have been

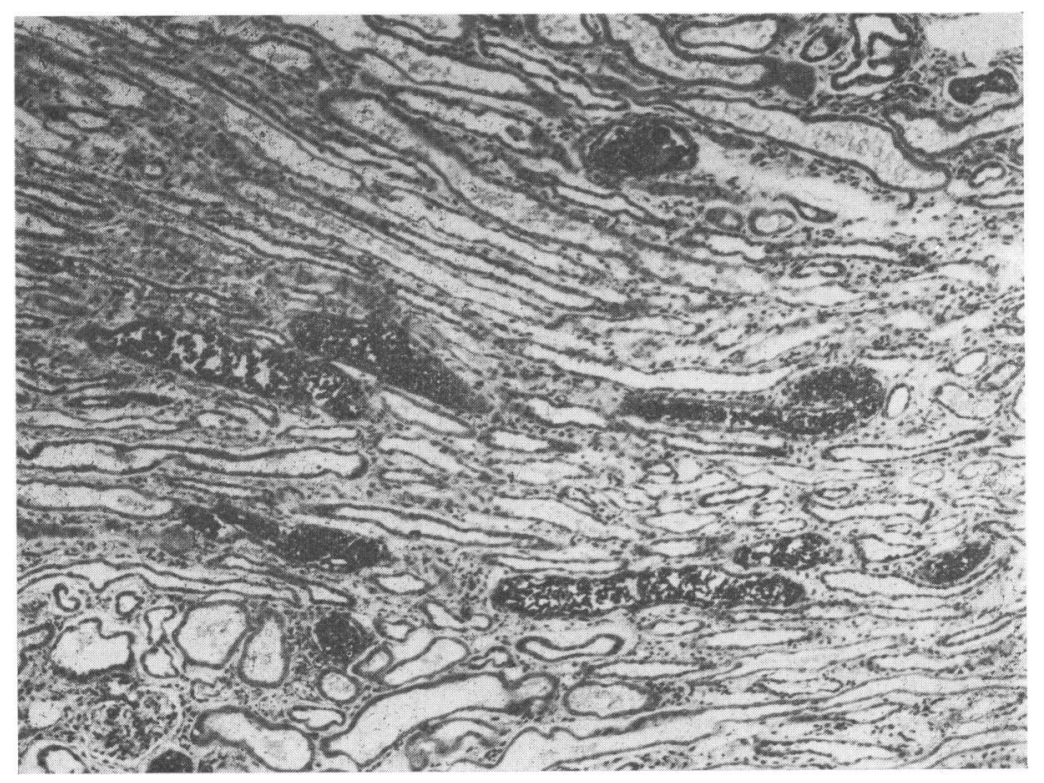

FIG. 4.-Multiple casts composed of red cells, their fragments, and fibrin-positive material in kidney of a premature breechborn baby. (Goldner's Trichrome. $\times 30$.) 


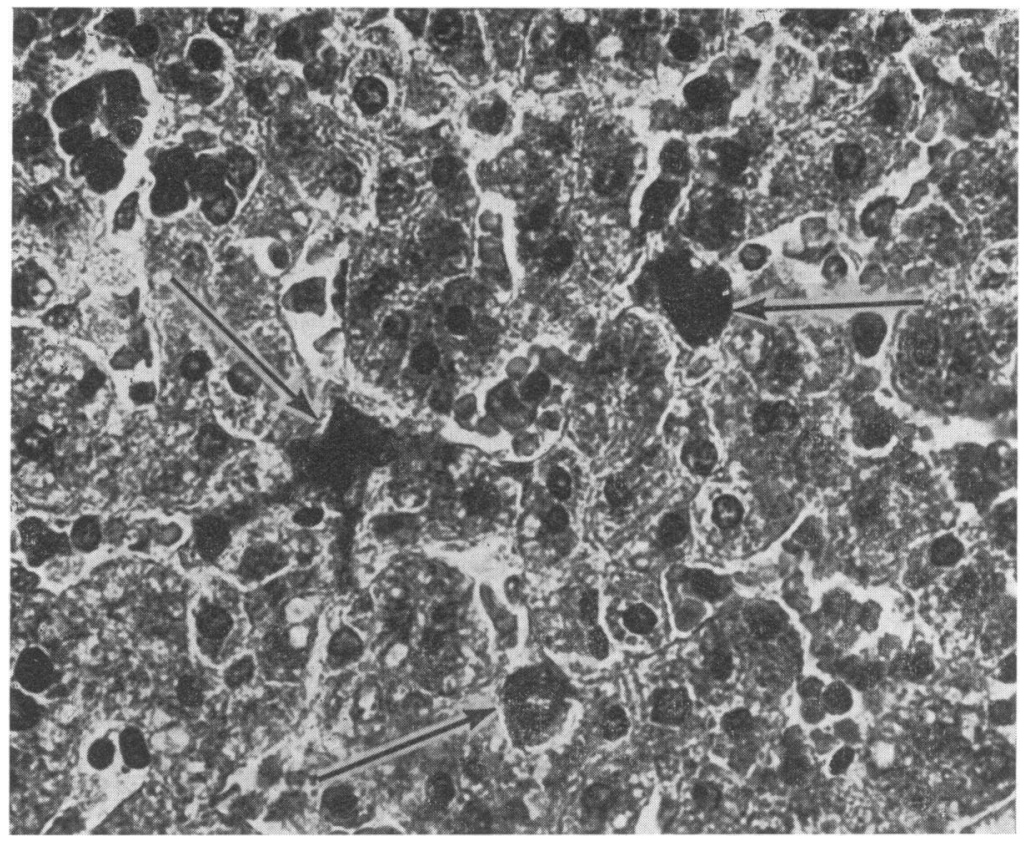

Fig. 5.-Multiple antemortem thrombi (arrowed) in liver. (Goldner's Trichrome. $\quad \times 330$.)

responsible for severe brain injury. In such cases, however, evidence of mechanical trauma to the brain and its meninges and vessels should be found.

Post-mortem dissection-vertex presentation ( 38 babies). The findings in 38 dissected babies born by normal delivery are shown in Table V. The damage was overall less frequent, less extensive, and histologically of milder degree. Nevertheless, the incidence of minor damage, especially in the neck and extremities, was surprisingly high. A comparison between this group and the group of breech presentation is shown in Table $\mathrm{V}$.

Babies surviving breech delivery ( 50 babies). Findings on 50 living mature babies examined

TABLE V

Distribution of muscle damage in babies dissected

\begin{tabular}{l|c|c}
\hline & $\begin{array}{c}\text { Vertex presentation } \\
\text { (38 babies) } \\
\text { (\% cases) }\end{array}$ & $\begin{array}{c}\text { Breech presentation } \\
\text { (86 babies) } \\
\text { (\% cases) }\end{array}$ \\
\hline Head and neck & 36 & 35 \\
Upper limb & 16 & 21 \\
Trunk & 8 & 21 \\
Lower limb & 29 & 92 \\
Genitalia and anus & 5 & 69 \\
\hline
\end{tabular}

during the first week after birth are shown in Table VI. The most frequent damage was skin bruising in the gluteal region, usually unilateral, and oedema of external genitalia. The area of skin involved was smaller on average and the damage was found less frequently than in those children who died. The fact that these babies with less extensive muscle damage survived breech delivery may be important.

TABLE VI

Distribution of muscle damage in babies dying after breech presentation

\begin{tabular}{l|c|c}
\hline & $\begin{array}{c}\text { Clinical } \\
\text { examination } \\
(50 \text { babies }) \\
(\% \text { cases })\end{array}$ & $\begin{array}{c}\text { Post-mortem } \\
\text { dissection } \\
(86 \text { babies }) \\
(\% \text { cases })\end{array}$ \\
\hline Gluteal region & 64 & 86 \\
Thigh & 6 & 78 \\
Lower leg & 6 & 47 \\
Foot & 10 & 67 \\
Genitalia and anus & 24 & 69 \\
\hline
\end{tabular}

\section{Discussion}

Injuries to muscles (with the exception of sternomastoid) in babies born by breech presentaiton are not generally recognized. A few reports briefly mention 'caput succedaneum' in the gluteal 
region or illustrate it among adjacent findings in descriptions of other neonatal damage (Nielson, Ferris, and Logan, 1948; Schwartz, 1964). Benešová (1958; personal communication, 1963) and O. Hněvkovský (personal communication, 1963) suggested their possible significance and the author is indebted to both for their encouragement in his early studies (Ráliš 1964, 1968a, b).

All injuries during breech delivery mentioned above are the result of the specific character of this labour. There is inadequate dilatation of the birth canal. The majority of the mothers are older primiparas whose babies also have the greatest mortality after breech delivery (Gaehtgens, 1942; Brosset, 1956; Hedberg, 1957). The membranes ruptured early in labour in $20-38 \%$ of cases (Kauffler, 1941; Todd and Steer, 1963), thus giving no protection to the leading part. The size of the part delivered first is also important: breech delivery by one foot is twice as dangerous as delivery by both feet (Zacharias and Heery, 1950). The leading part is usually represented by the huge muscle mass of the lower back, buttocks, and thighs. The alternation of positive pressure with negative pressure causes direct mechanical damage to the muscle fibres, soft tissue, and blood vessels. Venous infarction with perivascular and massive endomysial bleeding impairs the situation by local ischaemia and accelerates the necrosis of already damaged muscle fibres. Mechanical trauma, ischaemia, and haemorrhagic shock damage capillaries, produce intravascular clotting with further depletion of clotting factors, and further increase the bleeding. Thus there is a vicious circle of progressive bleeding into muscles already mechanically injured. The situation can be further impaired by the 'release' syndrome (Benison) which forms the background of 'tourniquet shock', whereby the circulation is suddenly deluged with disintegrated products from the crushed muscles and by toxic products of haemolysis, as soon as the damaged part is delivered and released.

This 'peripheral' trauma also touches on the widely discussed problem of whether birth injuries are due to asphyxia or to mechanical factors. During breech delivery the umbilical cord is often compressed in the narrow birth canal by the aftercoming head, causing severe asphyxia. The asphyxia not only damages the fetus generally but also affects its capillaries locally and impairs the circulatory metabolic conditions in the damaged tissue. It seems, however, that in term babies there is a prevalence of mechanical factors, as there is a direct relation between the severity of these injuries and the dilatation of the birth canal, the size of the fetus, and the time of rupture of membranes. The localization of bruising in various regions regularly follows the same pattern, and, in addition, there is histological evidence of direct trauma to muscle fibres. Prematurity also no doubt plays an important role in the trauma, as in preterm babies with immaturity of organs, fragility of vessels, disturbance of blood coagulation, and lack of protective subcutaneous tissue, injuries are more severe (Table VII).

TABLE VII

Severity of trauma in 86 breech-born babies: significance of prematurity

\begin{tabular}{l|c|c|c}
\hline & $\begin{array}{c}\text { No injury } \\
\text { (\% cases) }\end{array}$ & $\begin{array}{c}\text { Slight injury } \\
\text { (\% cases) }\end{array}$ & $\begin{array}{c}\text { Severe injury } \\
\text { (\% cases) }\end{array}$ \\
\hline $\begin{array}{l}\text { Preterm babies } \\
\text { Term babies }\end{array}$ & 5 & 8 & 87 \\
\hline
\end{tabular}

What are the possible consequences of trauma which the baby suffers during breech delivery? In babies that survive, smaller haemorrhages into muscles can be resolved, as would be expected from what is known about the excellent healing capabilities of newborn tissues. In more severe muscle damage and bruising, however, there is the possibility that repair by fibrosis may interfere with future limb development.

The findings of lower nephron nephrosis with fibrin-positive casts and evidence of scattered microthrombosis in 3 of 6 children who died shortly after birth with severe muscle injury, suggests that they suffered from crush syndrome and an episode of DIC. The complete necropsy on these babies, including dissection of the locomotor system, offers one possible explanation for these fatal conditions: extensive birth damage and haemorrhage into muscles resulting in haemorrhagic and traumatic shock. There are several published reports describing the presence of these fatal conditions in newborn babies.

Indirect clinical evidence that the muscles in breech delivery are crushed and damaged was supplied by Rudolph and Gross (1966), who studied the level of creatine phosphokinase in children after various types of delivery. Comparison of some of his figures from breech delivery and normal presentation shows that the highest level of this enzyme was found in breech-born babies. A mechanism similar to the damage of an extremity resulting from a long and difficult labour was reported by Muller and Muller (1952) in a case of fatal crush syndrome in a child where muscles of the 
trunk and arm were damaged and showed haemorrhage in the area of the mouth of a suction conduit to which the child had been stuck.

Lower nephron nephrosis in 3 newborns was described by Jonsson (1951). The babies, all born of primipara, suffered from 'severe asphyxia and shock, and acute renal insufficiency. Necropsy on one of the children revealed numerous brownish casts in distal renal tubules containing haemoglobin, and also multiple fibrinous thrombi and scattered areas of focal necrosis in liver. This appearance of casts in kidneys, which the author attributed to severe asphyxia and shock, is consistent with our findings of massively blocked renal tubules suggesting that traumatic uraemia (crush syndrome) took place.

The occasionally severe consequences of blood loss in newborn babies with large cephalhaematomata have been documented (Bernard and Sansot et Rapezzi, 1960; Tošovský, Stryhal, and Syrovátka, 1961; Janovský, 1963), and in our cases the volume of blood in crushed muscles was such that haemorrhagic shock may occur in these babies. The loss of blood could be especially dangerous when haemolysis or myolysis is present, since it is known that patients with crush syndrome tolerate blood loss badly. In Hardaway et al's experiments (1964) the mortality of haemorrhagic shock in dogs increased from $13 \%$ to $91 \%$ after the injection of 22 $\mathrm{ml}$ of their own haemolysed blood.

Finally, babies with severe muscle trauma resulting in stagnant capillary circulation, acidosis, and myolytic and haemolytic products accumulated in crushed tissues provide all the conditions necessary for development of DIC (Hardaway and Johnson, 1963; Hardaway, 1966; R. M. Hardaway, personal communication, 1970). Leissring and Vorlický (1968) reported a case of a newborn baby with asphyxia, brain damage, and haemorrhagic diathesis, in whom post-mortem microscopical examination revealed typical features of DIC. The baby with '... petechial rash over the buttocks and diffuse ecchymosis of the left flank...' was born to a 30-year-old primpara and died 7 days after breech extraction. Jonsson (1951) reported 3 newborn babies with acute renal insufficiency and 'severe asphyxia and shock', and described the typical DIC appearance in liver and brain of one. The appearance of microthrombi in our material resembles that in experimental traumatic shock and in DIC. Though the microthrombi are not always easy to find as they soon disappear, probably being lysed by endogenous fibrinolysin and then washed out. On the other hand, these changes are not merely 'agonal', as they are frequently seen in association with cellular infiltration and small areas of necrosis, and are never found in cases of trauma resulting in immediate death (Hardaway, 1966).

The majority of statistics dealing with neonatal mortality are based on routine post-mortem examination which does not usually involve dissection of the muscles, and though reporting on hundreds of babies dying after breech presentation, Gordon, Garlic, and Oginz (1934), Kauffler (1941), Schmitz, Smith, and Clumpner (1955), and Morgan and Kane (1964) failed to mention trauma to muscles among the possible causes of death. These surveys do state that in a proportion, $16 \%$ according to Schimitz et al., of cases the cause of death is unexplained. If analysis of the cause of the child's death is to be accurate, systematic post-mortem dissection of the muscles should be done after every difficult labour and malpresentation, time consuming though it admittedly is.

I thank Professor J. L. Emery, Sheffield Children's Hospital, for his encouragement.

\section{REFERENCES}

Benešová, D. (1958). Pathomorphological classification of the birth damage. Sborn. 9. ped. sjezdu, Brno, 1957. SPN, Praha (in Czech).

Bernard, R., and Sansot et Rapezzi, M. (1960). Anemia caused by extensive hematoma of the scalp in the newborn (apropos of five recent cases). Pédiatrie, 15, 588.

Brosset, A. (1956). Maternal morbidity and foetal mortality associated with breech presentation. Acta Obstetricia et Gynecologica Scandinavica, 35, 546.

Burger, P., Milfort, J., and Denef, R. (1962). Some considerations on breech presentation following new data on this subject. Gynécologie et Obstétrique (in French), 61, 461.

Elefant, E. (1957). One year's experience with babies born by breech presentation and Caesarean section. Ceskoslovenska Pediatrie (in Czech), 12, 687.

Gaehtgens, G. (1942). Dic Geburt in Quer-und Beckenendlage, p. 115. Dresden, Leipzig.

Gordon, C. A., Garlick, R., and Oginz, P. (1934). Analysis of 3301 breech deliveries in hospitals of Brooklyn, New York. American fournal of Obstetrics and Gynecology, 28, 140.

Hardaway, R. M. (1966). Syndromes of Disseminated Intravascular Coagulation. Thomas, Springfield, Illinois.

Hardaway, R. M., and Johnson, D. (1963). A unified theory of shock. American Surgeon, 29, 292.

Hardaway, R. M., Johnson, D. G., Elovitz, M. J., Houchin, D. N., Jenkins, E. B., Burns, J. W., and Jackson, D. R. (1964). Influence of trauma and hemolysis on hemorrhagic shock in dogs. Fournal of Trauma, 4, 624.

Hedberg, E. (1957). Breech deliveries: with special reference to foetal mortality. Acta Obstetricia et Gynecologica Scandinavica, 36, 356.

Janovsky, M. (1963). External cephalhaematomata and hyperbilirubinemia in newborn babies. Ceskoslovenská Pediatrie (in Czech), 18, 818.

Jonsson, B. (1951). Lower nephron nephrosis in asphyxia neonatorum. Acta Paediatrica, 40, 401.

Kauffler, R. (1941). Cause of the high mortality in pelvic presentation. Zentralblatt für Gynäkologie, 65, 1806.

Leissring, J. C., and Vorlický, L. N. (1968). Disseminated intravascular coagulation in a neonate. American fournal of Diseases of Children, 115, 100.

Morgan, H. S., and Kane, S. H. (1964). Analysis of 16,327 breech births. Fournal of the American Medical Association, 187, 262. 
Muller, M., and Muller, P. (1952). Un cas curieux de mort sous l'eau per action d'une énorme ventouse. Annales de Médecine Légale, Criminologie, Police Scientifique et Toxicologie, 32, 48.

Nielson, H. K., Ferris, D. O., and Logan, G. B. (1948). Injury of penis, scrotum and buttocks of the newborn resulting in gangrene. American fournal of Diseases of Children, 75, 85.

Ráliš, Z. A. (1964). Birth trauma to the gluteal region in a newborn. Paper read at a meeting of the Orthopaedic Club. Prague.

Ráliš, Z. A. (1968a). Trauma to newborn babies during breech delivery. Part 1. Visceral organs and locomotor system. M.D. Thesis, Faculty of Paediatrics, Charles University, Prague.

Ráliš, Z. A. (1968b), Trauma to newborn babies during breech delivery. Part 2. Muscle damage. M.D. Thesis. Faculty of Paediatrics, Charles University, Prague.

Rudolph, N., and Gross, R. T. (1966). Creatine phosphokinase activity in serum of newborn infants as an indicator of fetal trauma during birth. Prdiatrics, 38, 1039.

Schmitz, H. E., Smith, C. J., and Clumpner, E. R. (1955). End results of breech deliveries at Lewis Memorial Maternity Hospital based on a 21 year study. American fournal of Obstetrics and Gynecology, 69, 984.

Schwartz. P. (1964). Geburtsschäden bei Neugeborentn, p. 29. Fischer, Jena.

Smith. C. A. (1966). Blood Diseases of Infancy and Childhood, 2nd ed. Mosby, St. Louis.

Todd, W. D., and Steer, C. M. (1963). Term breech: review of 1006 term breech deliveries. Obstetrics and Gynecology, 22, 583.

Tošovský, V., Stryhal, F., and Syrovátka, A. (1961). The paediatric fractures. Státni Zdravotnické Nakladatelstvi (in Czech).

Zacharias, L. F., and Heery, R. (1950). An evaluation of breech presentation and vaginal delivery. American fournal of Obstetrics and Gynecology, 60, 1352.

Correspondence to Mr. Z. A. Ráliš, Department of Traumatic and Orthopaedic Surgery, Cardiff Royal Infirmary, Cardiff CF2 1SZ. 